\title{
"Hygienenetzwerk Südostniedersachsen" - a model for hygiene network formation in Germany
}

\author{
S Pfingsten-Würzburg ${ }^{1}$, M Plischke ${ }^{2}$, R Schubert ${ }^{1}$, W Bautsch ${ }^{3 *}$ \\ From International Conference on Prevention \& Infection Control (ICPIC 2011) \\ Geneva, Switzerland. 29 June - 2 July 2011
}

\section{Introduction / objectives}

Regional network formation is an integral part of any strategy to combat antimicrobial resistance development, as recommended by the German Antimicrobial Resistance Strategy (DART). But no information about the adequate organization in decentralized health systems such as Germany is given. Here, we report on the 'Hygienenetzwerk Südostniedersachsen $\hat{A}^{\prime}$ (HN-SON), a regional network in Lower Saxony, Germany, with special focus on organizational aspects.

\section{Methods}

Starting in 2009, a hygiene network of local health care providers was founded in Brunswick, Germany, moderated by the local health authority and focusing around the City Hospital, a major academic teaching hospital of $>1000$ beds.

\section{Results}

1. A hygiene network is an important source of information for many academic institutions, who may themselves offer important services free-of-charge in exchange. Thus, HN-SON soon cooperated with several institutions such as eHealth.Braunschweig on e. g. electronic patient admission-discharge management. 2.The majority of patient transferrals takes place within the catchment area of the major regional hospital. With HN-SON, this covers 8 health authority districts which soon cooperated in HN-SON. 3. HN-SON started as an informal association, an organization prohibitive to many activities, such as clinical studies, acceptance of donations and the cooperation with companies. We are currently founding a registered society which shall subsequently be incorporated into $\mathrm{HN}-\mathrm{SON}$.

\section{Conclusion}

These developments will hopefully expand our possibilities (as a juristic person) to offer better regional hygiene services, such as specialized training courses or a central help desk.

\section{Disclosure of interest}

None declared.

\section{Author details}

${ }^{1}$ Local Health Authority, Germany. ${ }^{2}$ BITZ Braunschweig Informatics and Technology Center, Germany. ${ }^{3}$ City Hospital Brunswick, Braunschweig, Germany.

Published: 29 June 2011
doi:10.1186/1753-6561-5-S6-P37
Cite this article as: Pfingsten-Würzburg et al:. "Hygienenetzwerk

Südostniedersachsen" - a model for hygiene network formation in Germany. BMC Proceedings 2011 5(Suppl 6):P37.

${ }^{3}$ City Hospital Brunswick, Braunschweig, Germany

Full list of author information is available at the end of the article

(c) 2011 Pfingsten-Würzburg et al; licensee BioMed Central Ltd. This is an open access article distributed under the terms of the Creative 